\title{
Induction of Hypersensitive Cell Death by a Fungal Protein in Cultures of Tobacco Cells
}

\author{
Akira Yano, ${ }^{1,2}$ Kaoru Suzuki, ${ }^{1}$ Hirofumi Uchimiya, ${ }^{2}$ Hideaki Shinshi ${ }^{1}$ \\ ${ }^{1}$ Plant Molecular Biology Laboratory, National Institute of Bioscience and Human-Technology, 1-1 Higashi, \\ Tsukuba, Ibaraki 305, Japan; ${ }^{2}$ Institute of Molecular and Cellular Biosciences, The University of Tokyo, \\ Yayoi, Bunkyo-ku, Tokyo 113, Japan \\ Accepted 13 October 1997.
}

Treatment of suspension-cultured tobacco (Nicotiana tabacum cv. Xanthi) cells (line XD6S) with fungal proteinaceous elicitors, namely, xylanase (EC 3.2.1.8) from Trichoderma viride $(\mathrm{TvX})$ and xylanase from $T$. reesei $(\mathrm{TrX})$, induced shrinkage of the cytoplasm, condensation of the nucleus, and, finally, cell death, which were accompanied by typical defense responses that included an oxidative burst and expression of defense genes. $\mathrm{A} \mathrm{Ca}^{2+}$ channel blocker, $\mathrm{Gd}^{3+}$, inhibited the typical response of XD6S cells to $\mathrm{TvX}$, which resembled the hypersensitive reaction (HR). These results suggested that the influx of $\mathrm{Ca}^{2+}$ ions plays an important role as a secondary signal. The HR was not observed in TvX-treated tobacco cells (line BY-2) derived from cv. Bright Yellow 2. This result suggests that key features of cultivar-specific interaction can be observed in cultures of tobacco cells. Xylanase from Bacillus circulans (BcX) and B. subtilis (BsX), which has enzymatic properties similar to those of TvX but an amino acid sequence different from that of TvX, did not induce the HR-like response in XD6S cells. These results suggest that the elicitor action of $\mathrm{TvX}$ is not due to its ability to hydrolyze cell walls but requires the $\mathrm{TvX}$-specific recognition factors in plant cells. Thus, TvX-induced cell death was not due to some general toxic effect, but seems to be mediated by the activation of a specific cellular signal-transduction cascade that converges with a pathway that activates the intracellular cell death program.

The hypersensitive reaction (HR) is one of the typical plant reactions against pathogen attack, the induction of which results from a specific recognition event between components of the host and the pathogen (Staskawicz et al. 1995; Dangl et al. 1996). The HR, which is a multifaceted defense mechanism, is characterized by the rapid and localized death of plant cells at the site of pathogen invasion, with numerous concurrent metabolic changes in challenged cells. Such changes include an oxidative burst, changes in ion fluxes, production of antimicrobial components (phytoalexins), rapid cross-linking of components of the cell wall, activation of the transcription of so-called defense genes, and, ultimately, resistance to the pathogen (Lamb et al. 1989; Atkinson et al. 1990; Bradley et

Corresponding author: K. Suzuki; Fax 81-298-54-6095;

E-mail skaoru@nibh.go.jp al. 1992; Mehdy 1994). This pathogen-induced hypersensitive cell death has often been described as a mechanism for restriction of the pathogen to the site of invasion by inhibition of its proliferation.

Hypersensitive cell death requires active plant metabolism and depends on the activity of the host's transcriptional and translational machinery (He et al. 1994). Cell death mutants, in which HR-like cell death occurs spontaneously or in response to environmental stimuli, have been identified in Arabidopsis (Dietrich et al. 1994; Greenberg et al. 1994; Weymann et al. 1995). Therefore, there has been considerable speculation that this physiologically important form of cell death might be regulated by the activation of a specific cellular program that is under genetic control. However, the molecular mechanism of cell death and the intracellular proteins that control it are not fully understood.

The molecular dissection of the mechanism of such cell death is difficult since the biological system involves intricate interactions between plant and pathogen. A simplified system, in which plant cells are synchronously challenged with a single molecular inducer of HR, would greatly facilitate studies of the molecular mechanism of development of the HR. Therefore, attempts have been made to identify elicitors, which are microbe- or plant-derived molecules, and to use them as tools with which to study the molecular events that link the initial perception of a pathogen signal to the expression of the plant's defense responses (Ebel and Cosio 1994). Several kinds of elicitors, which are components of pathogenic and nonpathogenic microorganisms, have been shown to trigger HR-like responses in plant tissues. These elicitors, including harpins and PopA1 from Pseudomonas spp. (Wei et al. 1992; Arlat et al. 1994), peptides encoded by the avirulence genes Avr 9 and Avr 4 of Cladosporium fulvum (Van den Ackerveken et al. 1992; Joosten et al. 1994), elicitins, and a 32-kDa glycoprotein from Phytophthora spp. (Billared et al. 1988; Ricci et al. 1989; Baillieul et al. 1995), have been shown to induce HR-like responses in infiltrated leaves.

In some cases, glycosyl hydrolases, secreted by pathogenic and nonpathogenic fungi, have been shown to activate the defense program of plants (Walton 1994). In most cases, it appears that plants do not recognize glycosyl hydrolases directly but, rather, they respond to the products of the enzymatically catalyzed reaction in the cell wall. Xylanase from the fungus Trichoderma viride (TvX) induces defense responses in leaves of tobacco (Bailey et al. 1990). It was proposed that it is the 
xylanase itself that is the elicitor and that the elicitor is not generated by degradation of plant cell walls (Sharon et al. 1993). TvX elicits defense responses in tobacco leaves in a cultivar-specific manner (Sharon et al. 1992) and the sensitivity of leaves of the Xanthi cultivar to TvX is controlled by a single dominant gene (Bailey et al. 1993). Therefore, the cultivar-specific response of TvX can be compared with the HR in incompatible plant-pathogen interactions.

Since the infection of plants by pathogens and the resulting defense responses occur initially at the single-cell level, suspension-cultured cells have been widely used as a simplified experimental system for investigations of the molecular mechanisms involved in plant-pathogen interactions. In combination with elicitors, such systems have provided excellent models for studies of various aspects of defense responses in plant cells. We have been investigating the elicitor signaltransduction pathway, which regulates known defense responses of plants, with suspension-cultured tobacco cells (Suzuki et al. 1995). Our previous studies showed that an influx of extracellular $\mathrm{Ca}^{2+}$ ions and protein kinase activity were necessary for the elicitor-induced transcription of several defense genes. In addition, we identified an elicitor-responsive 47-kDa protein kinase (Suzuki and Shinshi 1995) that might actually be a mitogen-activated protein kinase (Chasan 1995).
During our studies, we examined putative elicitors in this system, and we found that TvX can induce HR-like responses in cultured tobacco cells. We describe here the fungal proteininduced hypersensitive cell death of tobacco cells in a cell line-specific manner, with an associated oxidative burst and the accumulation of transcripts of defense genes.

\section{RESULTS}

\section{Induction of cell death by fungal xylanase.}

We showed previously that suspension-cultured tobacco cells (line XD6S) respond to a fungal elicitor by activation of the transcription of defense genes (Suzuki et al. 1995). To establish an experimental model system with which to study the molecular mechanisms of elicitor-induced hypersensitive cell death in plants, we examined the effects of TvX on XD6S cells. When TvX was added to a suspension of XD6S cells at the final concentration of $1 \mu \mathrm{g} / \mathrm{ml}(48 \mathrm{nM})$, marked changes in the morphology of cells were observed, as shown in Figure 1. Treatment with TvX caused browning of cells, shrinkage of cytoplasm that resembled plasmolysis, and condensation of nuclei, suggesting that the cells might have died in a manner consistent with the induction of programmed cell death. The viability of TvX-treated tobacco cells was determined by dou-
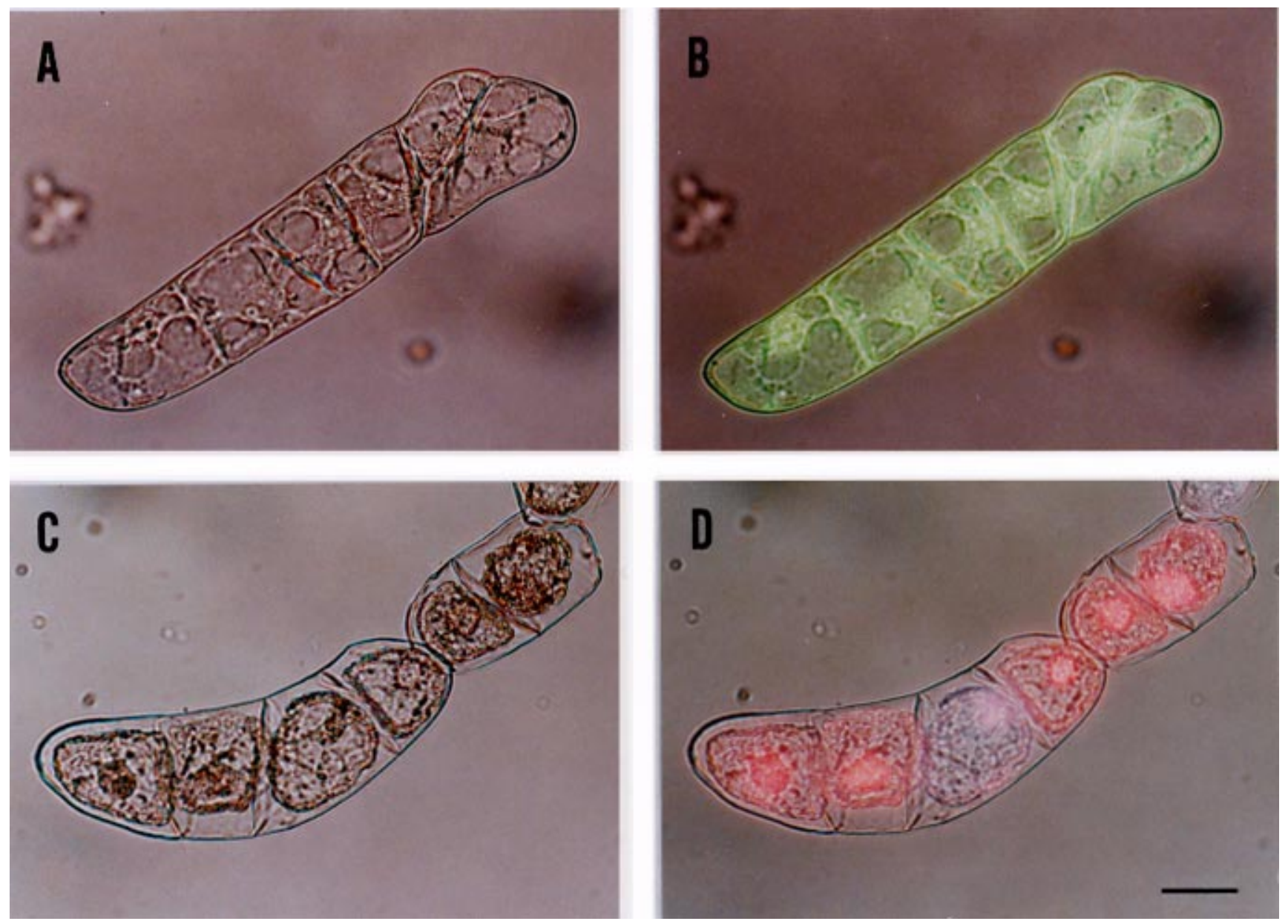

Fig. 1. Morphological changes in tobacco XD6S cells induced by TvX. A and B, XD6S cells before addition of TvX. C and D, XD6S cells $24 \mathrm{~h}$ after addition of TvX at a final concentration $1 \mu \mathrm{g} / \mathrm{ml}$. Cells were double-stained with fluorescence diacetate (FDA) and propidium iodide (PI). Images on the left $(\mathbf{A}, \mathbf{C})$ were photographed under visible light; those on the right $(\mathbf{B}, \mathbf{D})$ were photographed under visible and UV light. Bar represents $50 \mu \mathrm{m}$. 
ble staining with fluorescein diacetate (FDA) and propidium iodide (PI), and subsequent fluorescence microscopy (Widholm 1972; Cornillon et al. 1994). FDA, a hydrophobic molecule, enters cells passively and is then cleaved by cytoplasmic enzymes, becoming both fluorescent at green wavelengths and charged, such that it is unable to leave the cells. Thus, this stain labels viable cells with an intact plasma membrane. PI can only enter cells whose plasma membranes have altered permeability and then it stains, in particular, nucleic acids, emitting mostly red fluorescence. In the absence of treatment with TvX, most cells remained viable throughout the incubation period, and they were stained with FDA. In the case of TvX-treated cells, green fluorescence gradually decreased, almost disappearing within $6 \mathrm{~h}$, and condensed nuclei became stainable with PI. As judged by double staining, 60 to $70 \%$ of TvX-treated cells had died after $24 \mathrm{~h}$.

\section{Induction of defense responses of XD6S cells by fungal xylanase.}

Evans blue is excluded from intact, viable cells but it remains in dead cells. Therefore, it can be used to monitor the kinetics of cell death. Treatment of XD6S cells with TvX resulted in a rapid increase in the number of dead cells after $3 \mathrm{~h}$, as monitored by staining with Evans blue (Fig. 2A), and the number increased with increasing concentrations of TvX. Hypersensitive cell death is accompanied by the induction of various defense responses. Previous studies have shown that the production of active oxygen species is an early defense response. The TvX-dependent release of active oxygen species into the culture medium was measured by monitoring luminol-dependent chemiluminescence (Schwacke and Hager 1992). In the medium of treated cultures, we observed increase in chemiluminescence with this assay. The chemiluminescence represented the accumulation of $\mathrm{H}_{2} \mathrm{O}_{2}$ in the medium since the elicitor-induced increase in chemiluminescence was completely eliminated in the presence of catalase (data not shown). The level of $\mathrm{H}_{2} \mathrm{O}_{2}$ in the medium began to increase from 1 to $2 \mathrm{~h}$ after the addition of TvX, reaching a maximum after about $3 \mathrm{~h}$ and falling to the background level after $6 \mathrm{~h}$ (Fig. 3B).

Hypersensitive cell death is accompanied by the activation of transcription of defense genes. In a previous study, we demonstrated that XD6S cells respond to fungal elicitor derived from the cell walls of Phytophthora infestans (Pi elicitor) by the differential expression of defense genes (Suzuki et al. 1995). As shown in Figure 2B, TvX also induced the accumulation of mRNAs for class I basic chitinase (BCHN) and class II acidic chitinase (ACHN), with different kinetics in each case. The level of mRNA for ATP synthase (ATPS), as a loading control, decreased gradually with the progression of cell death. Because the level of mRNA for ATPS is usually stable in living cells during treatment with the Pi elicitor, the decrease in the level of mRNA for ATPS was assumed to be the result of cell death.

\section{Effect of a $\mathrm{Ca}^{2+}$ channel blocker on the TvX-induced HR-like response.}

An influx of $\mathrm{Ca}^{2+}$ ions has been implicated in the activation of early defense responses that include extracellular alkalization, the oxidative burst, and transcription of defense genes by elicitors (Kombrink and Somssich 1995; Jabs et al. 1997). To examine the possible involvement of $\mathrm{Ca}^{2+}$ ions in the TvXinduced, HR-like response of tobacco cells in culture, we added a $\mathrm{Ca}^{2+}$ channel blocker, $\mathrm{Gd}^{3+}$, just before addition of TvX. $\mathrm{Gd}^{3+}$ ions have been shown to inhibit the cold-shockinduced increases in the cytosolic levels of $\mathrm{Ca}^{2+}$ ions in tobacco seedlings (Knight et al. 1992). As shown in Figure 3, the TvX-induced oxidative burst, the expression of defense genes, and cell death were prevented by $5 \mathrm{mM} \mathrm{Gd}^{3+}$ ions. Bailey et al. (1992) reported that TvX-induced $\mathrm{Ca}^{2+}$ uptake of tobacco suspension cells was inhibited by $\mathrm{Ca}^{2+}$ channel blocker $\mathrm{La}^{3+}$, and we also confirmed that $\mathrm{La}^{3+}$ inhibited TvXinduced cell death (data not shown). These results suggest that the HR-like response of tobacco cells elicited by TvX requires

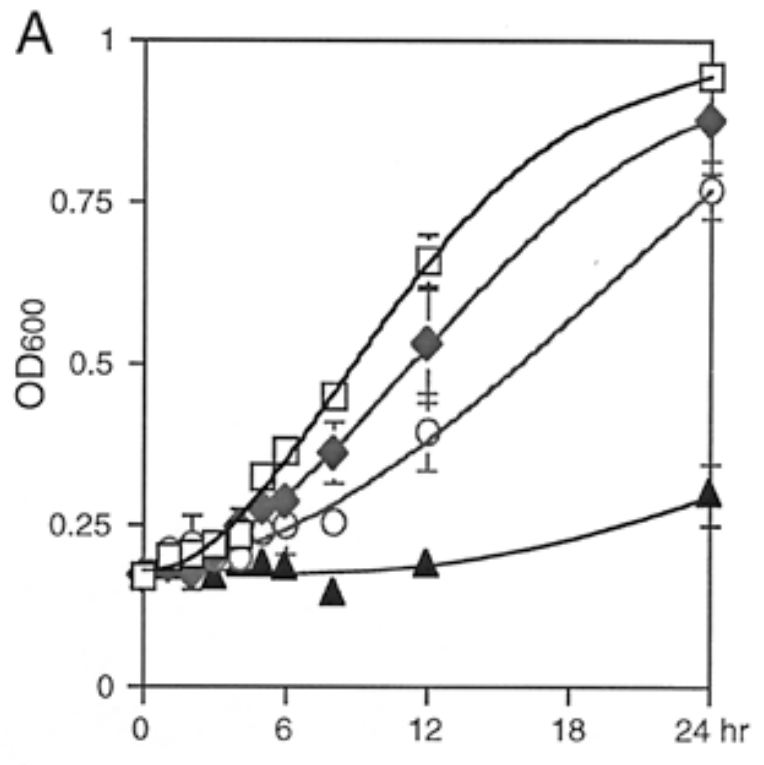

B

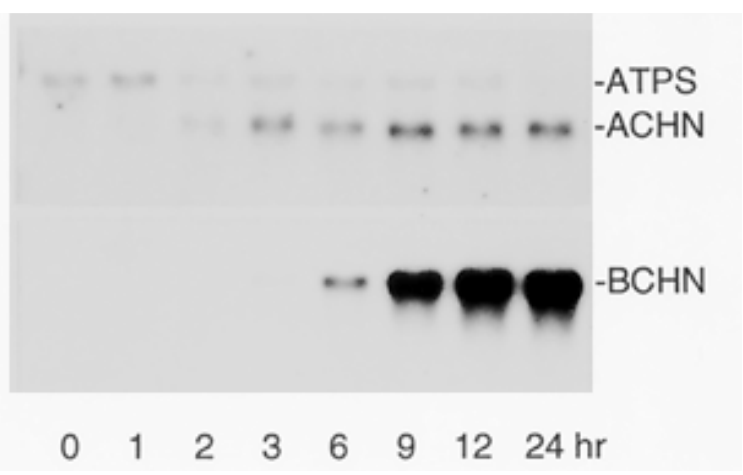

Fig. 2. Kinetics of cell death and induction of defense genes. A, Kinetics of cell death, as examined by staining with Evans blue. XD6S cells were treated with $\mathrm{TvX}$ at various concentrations (solid triangle = control; open circle $=0.2 \mu \mathrm{g}$ of TvX per ml; solid diamond $=1 \mu \mathrm{g}$ of TvX per $\mathrm{ml}$; open square $=5 \mu \mathrm{g}$ of TvX per $\mathrm{ml}$ ). Cell death was determined spectrophotometrically with Evans blue as described in Materials and Methods. Data were expressed as means of three experiments \pm SD. B, Induction of defense genes in XD6S cells by TvX. XD6S cells were treated with $1 \mu \mathrm{g}$ of TvX per ml, and levels of transcripts of genes for class I basic chitinase (BCHN), class II acidic chitinase (ACHN), and ATP synthase (ATPS) were analyzed after incubation for 0 to $24 \mathrm{~h}$, as described in Materials and Methods. 
an influx of $\mathrm{Ca}^{2+}$ ions across the plasma membrane and that elevation of the cytosolic level of $\mathrm{Ca}^{2+}$ ions might play an important role in the signal transduction cascades that lead to HR-like responses. On the other hand, $1 \mathrm{mM} \mathrm{Gd}^{3+}$ ion inhibited the induction of defense genes and cell death, and partially inhibited the induction of the oxidative burst. A low concentration of $\mathrm{Ca}^{2+}$ ions may be sufficient to induce the oxidative burst.

\section{A}
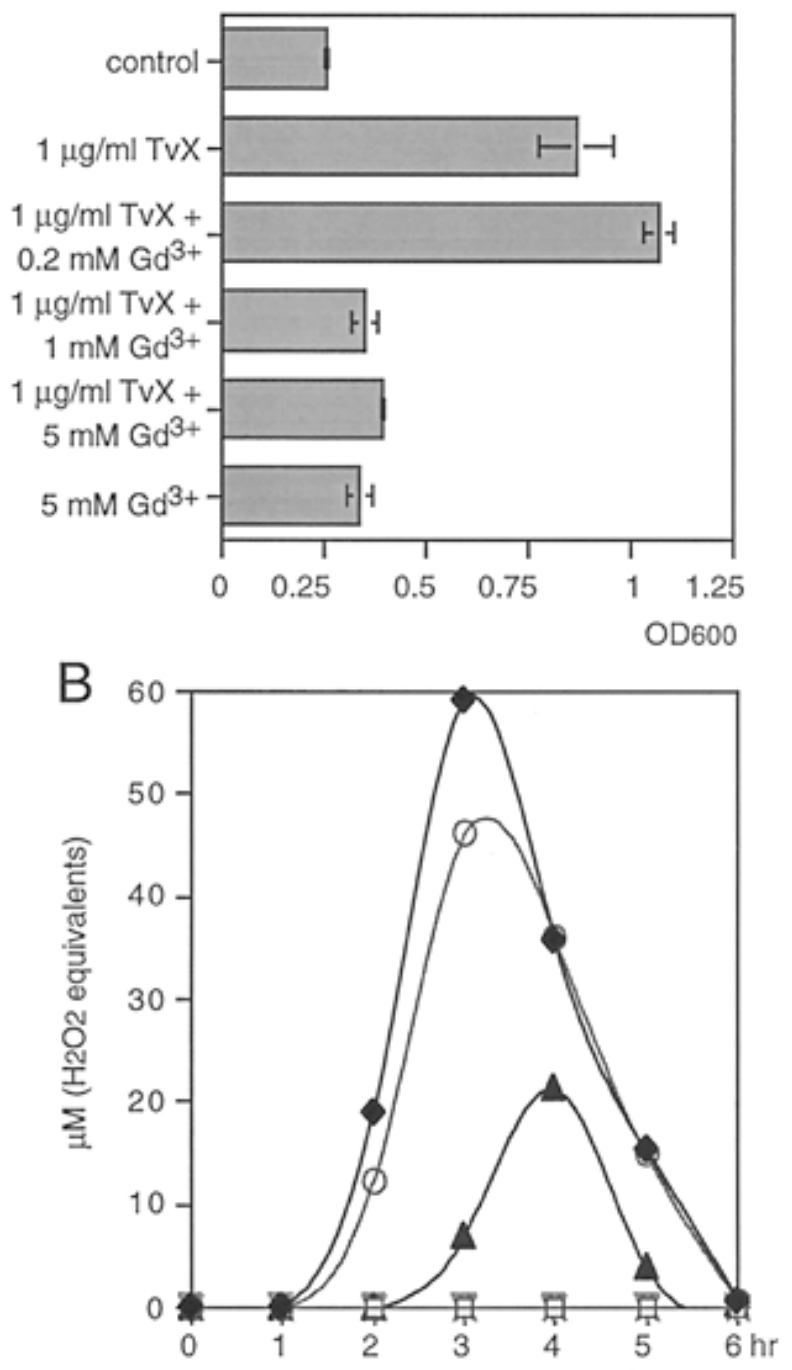

C

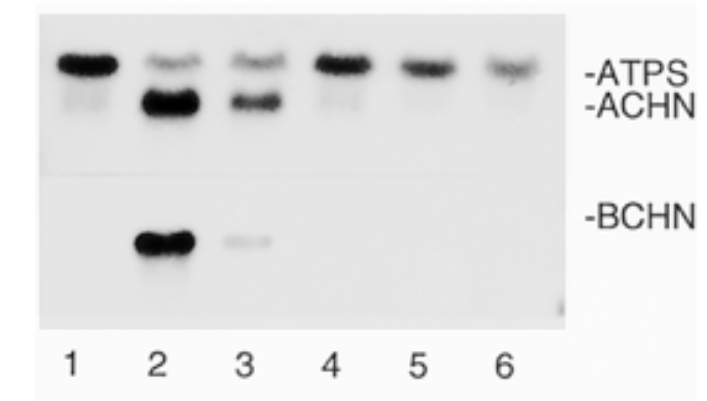

\section{Specific interaction between TvX} and the tobacco cultivar Xanthi.

The HR-like response of TvX is induced in the Xanthi cultivar but not in the Hicks cultivar of tobacco (Sharon et al. 1992). In suspension cultures of tobacco cells, TvX induced the HR-like response in cells of the XD6S line, which was derived from the tobacco cultivar Xanthi (Yamaoka et al. 1969). However, TvX did not induce the death of cells of another cell line, namely, BY-2, which was derived from the tobacco cultivar Bright Yellow 2 (Kato et. al. 1972), as shown in Figure 4. TvX elicited neither the oxidative burst (data not shown) nor the death of cells in cultures of BY-2 cells. These results suggest that the lethal activity of $\mathrm{TvX}$ was not due to some general toxic effect on tobacco cells but required a TvXspecific recognition factor in the plant cells.

To determine whether or nor xylanase activity is enough for the elicitor action of TvX, we examined the HR-eliciting activity of closely related basic $\beta-1,4$-endoxylanases of low molecular mass. The enzymatic properties of xylanases from T. reesei (TrX; Ujiie et al. 1991; Törrönen et al. 1992) and Bacillus circulans (BcX; Yang et al. 1989) are almost identical to those of TvX. The amino acid sequences of TvX and $\mathrm{TrX}$ are rather similar but there are many differences between $\operatorname{Tr} \mathrm{X}$ and $\mathrm{BcX}$, except in the case of those amino acid residues that are necessary for catalytic activity. The amino acid sequences of $\mathrm{TvX}$ and $\mathrm{BcX}$ are $47 \%$ homologous. By contrast, the amino acid sequence of $\operatorname{Tr} X$ is identical, with the exception of three amino acid substitutions, to that of TvX (Törrönen et al. 1992). If elicitor activity were to be related to the cell wall-degradative xylanase activity and if $\mathrm{XD} 6 \mathrm{~S}$ cells were to recognize the products of hydrolysis as the elicitor, these xylanases might be expected to induce the HR-like response in XD6S cells. Each xylanase was added to a culture of XD6S cells and cell death was monitored after $24 \mathrm{~h}$ by staining with Evans blue. As shown in Figure 5, both xylanases from Trichoderma (TvX and $\operatorname{TrX}$ ) induced cell death and the accumulation of transcripts of defense genes but $\mathrm{BcX}$ did not.

Fig. 3. Effects of $\mathrm{Gd}^{3+}$ ions on the TvX-induced hypersensitive reactionlike response of XD6S cells. A, Inhibition of TvX-induced cell death by $\mathrm{Gd}^{3+}$ ions. $\mathrm{Gd}^{3+}$ ions were added at $0.2,1$, or $5 \mathrm{mM}$ just before addition of $1 \mu \mathrm{g}$ of TvX per ml to cultures and cell death was monitored staining with Evans blue after a 24-h incubation as described in Materials and Methods. Data were expressed as means of three experiments \pm SD. B, Inhibition of the accumulation of active oxygen species in the culture medium of XD6S cells by $\mathrm{Gd}^{3+}$ ions. $\mathrm{Gd}^{3+}$ ions were added just before addition of TvX. Levels of active oxygen species are expressed in terms of micromoles of $\mathrm{H}_{2} \mathrm{O}_{2}$, monitored by the chemiluminesences assay, as described in Materials and Methods (open square = control; solid diamond $=1 \mu \mathrm{g}$ of TvX per ml; open circle $=1 \mu \mathrm{g}$ of TvX per $\mathrm{ml}+0.2 \mathrm{mM}$ $\mathrm{Gd}^{3+}$; solid triangle $=1 \mu \mathrm{g}$ of TvX per $\mathrm{ml}+1 \mathrm{mM} \mathrm{Gd}^{3+}$; solid cross $=1$ $\mu \mathrm{g}$ of TvX per $\mathrm{ml}+5 \mathrm{mM} \mathrm{Gd}^{3+}$; solid inverted triangle $=5 \mathrm{mM} \mathrm{Gd}^{3+}$ ). Similar profiles were seen in three independent experiments. $\mathbf{C}$, Effects of $\mathrm{Gd}^{3+}$ ions on the induction of defense genes by TvX. $\mathrm{Gd}^{3+}$ ions were added just before addition of TvX to cultures. Levels of transcripts of genes for class I basic chitinase (BCHN), class II acidic chitinase (ACHN), and ATP synthase (ATPS) $6 \mathrm{~h}$ after addition of TvX were analyzed as described in Materials and Methods (lane $1=$ control; lane $2=$ $1 \mu \mathrm{g}$ of TvX per ml; lane $3=1 \mu \mathrm{g}$ of TvX per $\mathrm{ml}+0.2 \mathrm{mM} \mathrm{Gd}^{3+}$; lane 4 $=1 \mu \mathrm{g}$ of TvX per $\mathrm{ml}+1 \mathrm{mM} \mathrm{Gd}^{3+}$; lane $5=1 \mu \mathrm{g}$ of TVX per $\mathrm{ml}+5$ $\mathrm{mM} \mathrm{Gd}^{3+}$; lane $\left.6=5 \mathrm{mM} \mathrm{Gd}^{3+}\right)$. 
For further experiments on specific interactions between xylanases and tobacco cells, we used recombinant xylanases produced in Escherichia coli. Fragments of cDNAs, encoding xylanase from B. subtilis (BsX) and xylanase II from T. reesei, were amplified by polymerase chain reaction (PCR) from the DNA of B. subtilis and by PCR after reverse transcription of mRNA from $T$. reesei, respectively. Then $\mathrm{BsX}$ and $\mathrm{TrX}$ were synthesized as fusion proteins with glutathione $\mathrm{S}$-transferase (GST) in E. coli. The GST protein was removed from the purified fusion proteins by digestion with thrombin and the xylanases were purified as described in Materials and Methods. Recombinant BsX (BsXre) and BcX had the same amino acid sequences with one difference of residue 247 . Recombinant $\operatorname{TrX}$ (TrXre) included eight extra amino acids from the vector at the amino terminus. The preparations of recombinant xylanases were almost homogeneous, as determined by sodium dodecyl sulfate-polyacrylamide gel electrophoresis and shown in Figure 6A. The activities of the xylanases were assayed with 4-O-methyl-D-glucurono-D-xylan-Remazol Brilliant Blue $\mathrm{R}$ (RBB-Xylan) as the substrate (Fig. 6B; Biely et al. 1988), and xylanase activities of TrXre and BsXre under the conditions of the cell-death assay $\left(26^{\circ} \mathrm{C}, \mathrm{pH} 5.8\right)$ were confirmed. Then we examined the cell death-inducing activities of TrXre and BsXre by staining with Evans blue (Fig. 6C). TrXre induced the death of tobacco XD6S cells. By contrast, BsXre did not have cell death-inducing activity even when we used a high concentration of BsXre, with xylanase activity several-fold higher than that of $\mathrm{TvX}$ at $1 \mu \mathrm{g} / \mathrm{ml}$. These results indicated that the $\beta-1,4$-endoxylanase activity was not related to the HReliciting activity and that only the pure xylanase from Trichoderma was able to elicit the death of XD6S cells in culture.

\section{DISCUSSION}

Treatment of tobacco cells in suspension cultures with TvX caused hypersensitive cell death. We exploited this fact to establish an experimental system with which to study the mo-

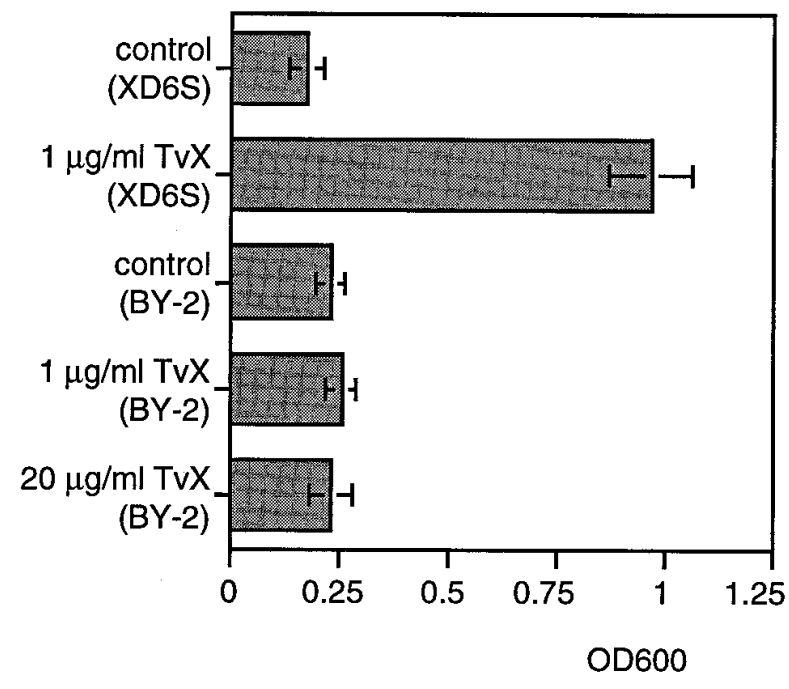

Fig. 4. Effects of TvX on XD6S cells and BY-2 cells. TvX was added to cultures of XD6S cells and BY-2 cells at a final concentration of $1 \mu \mathrm{g} / \mathrm{ml}$ or $20 \mu \mathrm{g} / \mathrm{ml}$. After a 24-h incubation, cell death was determined by staining with Evans blue as described in Materials and Methods. Data were expressed as means of three experiments \pm SD. lecular mechanism of elicitor-inducible cell death in plants. TvX is a proteinaceous elicitor of the HR-like response in tobacco. Treatment of leaves of the tobacco cultivar with TvX induces an HR-like response, with formation of necrotic lesions, production of pathogenesis-related proteins, and the production of ethylene, in a cultivar-specific manner (Sharon et al. 1992; Bailey et al. 1993; Avni et al. 1994). In the present study, we showed that the treatment of tobacco XD6S cells with TvX resulted not only in typical defense responses, which included an oxidative burst and an increase in levels of transcripts of defense genes, but also cell death. The use of both a purified proteinaceous elicitor of HR and a suspension culture of cells that are responsive to the elicitor should facilitate investigations of the molecular events in the plant HR. The induction by an elicitor of hypersensitive cell death in plant cells in suspension culture has rarely been reported.
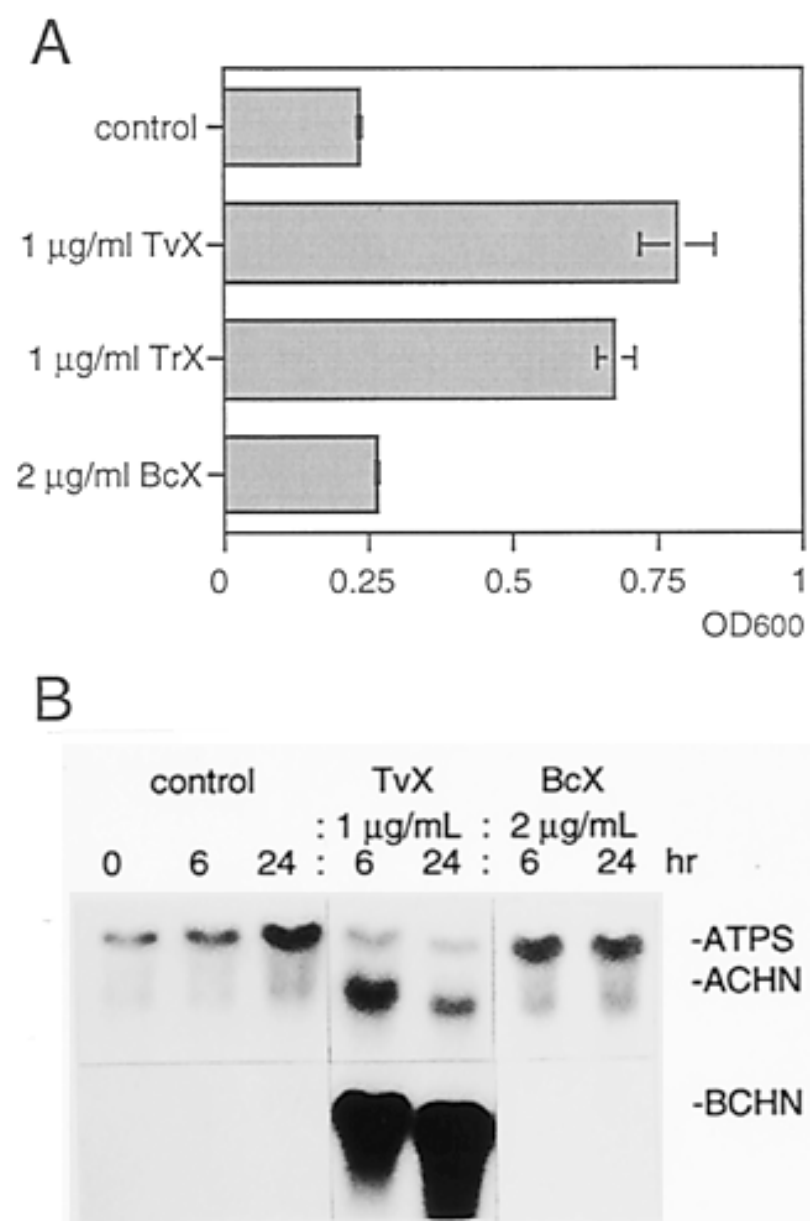

Fig. 5. Effects of various xylanases on XD6S cells. A, Induction of cell death by xylanases. TvX, TrX, and BcX were added to cultures of XD6S cells at $1 \mu \mathrm{g} / \mathrm{ml}, 1 \mu \mathrm{g} / \mathrm{ml}$, and $2 \mu \mathrm{g} / \mathrm{ml}$, respectively. After a 24-h incubation, cell death was determined by staining with Evans blue as described in Materials and Methods. The specific activity of BcX was approximately half that of TvX. Data were expressed as means of three experiments \pm SD. B, Induction of the transcription of defense genes by xylanases. $\mathrm{TrX}$ and $\mathrm{BcX}$ were added to cultures of XD6S cells at $1 \mu \mathrm{g} / \mathrm{ml}$ and $2 \mu \mathrm{g} / \mathrm{ml}$, respectively. After 6-h and 24-h incubations, levels of transcripts of genes for class I basic chitinase (BCHN), class II acidic chitinase (ACHN), and ATP synthase (ATPS) were analyzed as described in Materials and Methods. 
However, several microbial proteins and products of avirulence genes have been shown to act as elicitors of the HR in plant tissues and they elicit biochemical changes, such as an oxidative burst, extracellular alkalization, and the formation of ethylene, but not the death of cells in suspension cultures (Baker et al. 1993; Tavernier et al. 1995). Thus, to our knowledge, this is the first report demonstrating that a purified elicitor of the HR can induce hypersensitive cell death in a plant culture system composed of homogeneous cells.

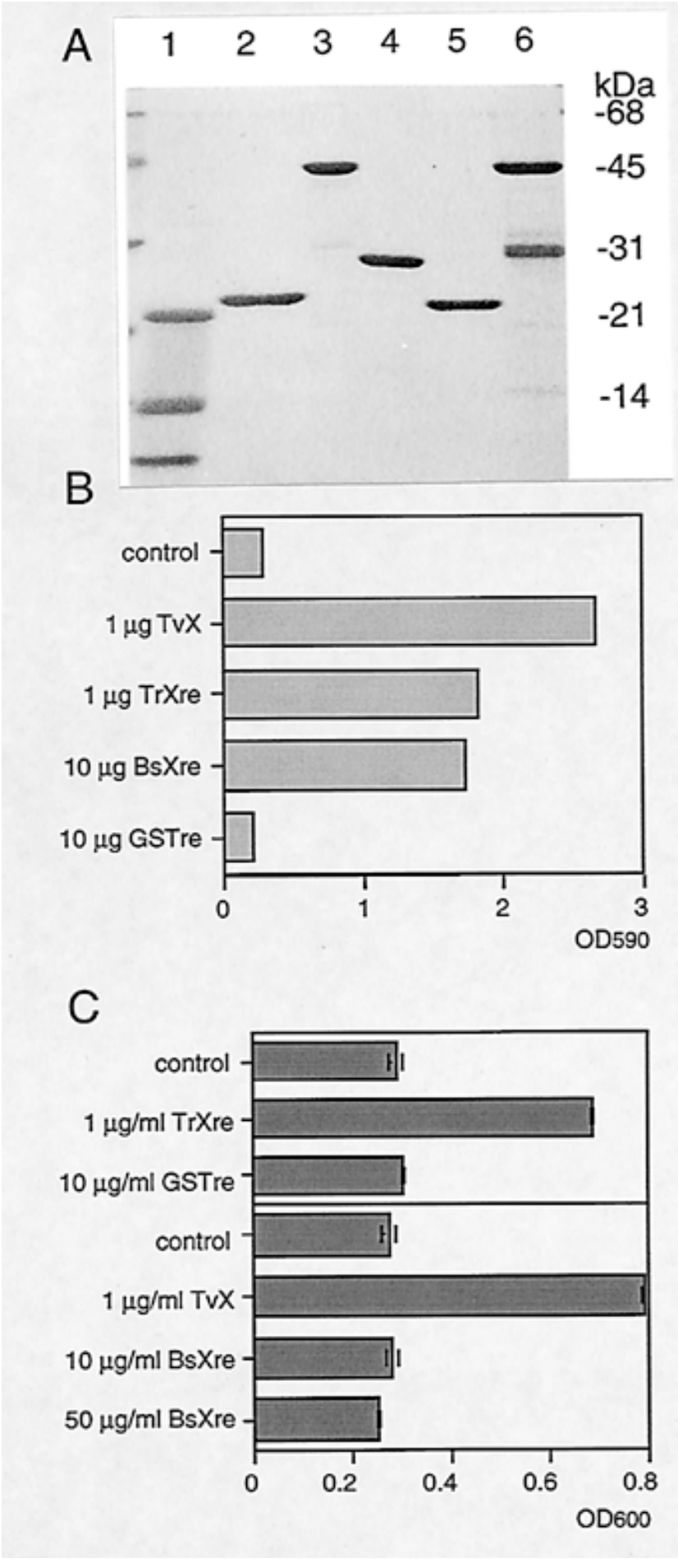

Proteinaceous elicitors with glyco-hydrolytic enzymatic activity have been isolated from fungi, and it was shown that compounds with elicitor activity are released from the cell walls of plants or pathogens as a result of this hydrolytic activity (Hahn et al. 1989; Bucheli et al. 1990). However, TvX does not release any detectable heat-stable elicitor during the interaction between the xylanase and tobacco leaves (Fuchs et al. 1989) or xylan (Dean et al. 1989). It does, however, induce the production of ethylene in protoplasts from tobacco leaves and it reduces the viability of the protoplasts (Sharon et al. 1993). These observations suggest that elicitation of plant responses by TvX might result from the direct interaction of the polypeptide with the cell and might not involve any intermediate compounds. The suggestions are supported by our results that $\mathrm{BcX}$ and $\mathrm{BsX}$, which have different primary structures from two cognate xylanases, $\operatorname{TvX}$ and $\operatorname{TrX}$, that induce HR-like responses, failed to induce defense responses and cell death in cultures of XD6S cells even though all xylanases have similar enzymatic properties (Yang et al. 1989; Ujiie et al. 1991; Törrönen et al. 1992).

It was reported previously that TvX elicits an HR-like response in the tobacco cultivar Xanthi but not in the Hicks cultivar and that the specific interaction between TvX and Xanthi is controlled by a single dominant gene (Bailey et al. 1993). In this study, we also demonstrated that key features of this specific interaction can be observed in cultures of tobacco cells. Thus, TvX caused hypersensitive cell death in cultures of XD6S cells that originated from the tobacco cultivar Xanthi but not in cultures of BY-2 cells derived from tobacco cultivar Bright Yellow 2. Moreover, we have also found that infiltrated TvX and TrX are able to induce lesions on leaves of the Xanthi cultivar and also on leaves of the Xanthi nc cultivar but not on leaves of the Bright Yellow 4 cultivar (A. Yano, K. Suzuki, and $\mathrm{H}$. Shinshi, unpublished results). The structure and function of the gene product that controls the responsiveness of tobacco to TvX is unknown. In all the models that have been proposed to explain the mechanism of induction of the hypersensitive cell death that results from the incompatible interaction between a plant and the corresponding pathogen, it is proposed that the incompatible interaction is based on the specific recognition of an elicitor of HR by the host plant. Hypersensitive cell death is thought to be initiated primarily at single plant cells and the elicitors are perceived by corresponding receptors on the plant cells. However, direct interactions be-

Fig. 6. Analysis of recombinant xylanases, synthesized in Escherichia coli. A, Analysis by sodium dodecyl sulfate-polyacrylamide gel electrophoresis (SDS-PAGE) of preparations of xylanases. Preparations of TvX (lane 1), recombinant $\operatorname{TrX}$ (TrXre: lane 2), GST-TrX (lane 3), recombinant GST (GSTre: lane 4), recombinant BsX (BsXre: lane 5), and GSTBsX (lane 6), were subjected to SDS-PAGE (5 $\mu \mathrm{g}$ of protein per lane) and then the gel was stained with Coomassie brilliant blue, as described in Materials and Methods. B, Xylanase activity of recombinant xylanases, as determined with RBB-xylan. The xylanase activities of TvX, TrXre, BsXre, and GSTre were examined as described in Materials and Methods. Similar profiles were seen in three independent experiments. C, The ability of the recombinant xylanases to induce cell death. Cultures of XD6S cells were treated with recombinant proteins for $24 \mathrm{~h}$. Then the cell death-inducing activity of each protein was determined by staining with Evans blue as described in Materials and Methods. Data were expressed as means of three experiments \pm SD. 
tween the elicitor and receptor have not been demonstrated in plants, even though high-affinity binding sites for pathogenderived elicitors, which can induce defense responses in plant tissues, have been demonstrated on plasma membranes of plant cells (Nürnberger et al. 1994; Kooman-Gersmann et al. 1996). The experimental system with suspension-cultured cells that are responsive to TvX should facilitate investigations of binding sites for the elicitor of HR.

Hypersensitive cell death is believed to be an actively programmed process in plant cells. As proposed previously, it seems reasonable to speculate that the activation of preexisting components, which include ion channels in plasma membranes, protein kinases, protein phosphatases, G-proteins, and enzymes that generate active oxygen species, occurs immediately after perception of the elicitor (Lamb 1994; Low and Media 1995; Staskawicz et al. 1995; Bent 1996; Suzuki and Shinshi 1996; Hammond-Kosack and Jones 1996). In plants, an influx of $\mathrm{Ca}^{2+}$ ions was suggested by several authors to be involved in the bacterial induction of hypersensitive cell death (Atkinson et al. 1990; Levine et al. 1996). In mammalian cells, an influx of $\mathrm{Ca}^{2+}$ ions has also often been implicated in the induction of apoptosis, which is one of the most widely studied forms of programmed cell death in animals (Martin et al. 1994). In the present study, our results with $\mathrm{Gd}^{3+}$ ions suggested that an influx of extracellular $\mathrm{Ca}^{2+}$ ions might be crucial for the early steps of the signal transduction pathway for the induction of hypersensitive cell death, as well as for defense responses in TvX-treated tobacco cells. Similar effects of a $\mathrm{Ca}^{2+}$ channel blocker were reported in the case of a harpin-elicited HR in tobacco leaves (He et al. 1994). Thus, TvX-induced cell death seems to be an active process that is mediated by the activation of a specific signal-transduction cascade that originates from a putative receptor for xylanase. The cascade converges with a pathway that activates the intracellular suicide program. The availability of a model system should facilitate the biochemical analysis of the ligandinducible processes that lead to hypersensitive cell death, and the system should also provide a tool for the isolation and identification of the specific components that are responsible for cell death and survival.

\section{MATERIALS AND METHODS}

\section{Plant materials and elicitors.}

Suspension cultures of tobacco cells (Nicotiana tabacum, lines XD6S and BY-2) were subcultured under the conditions described previously (Yamaoka et al. 1969; Kato et al. 1972). Xylanase from Trichoderma viride was obtained from Sigma (St. Louis, MO). Homogeneous preparations of xylanases from Trichoderma reesei and xylanase from Bacillus circulans were kindly provided by K. Ishikawa (National Institute of Bioscience and Human Technology [NIBH], Tsukuba, Japan). Specific activities of $\mathrm{TvX}$ and $\mathrm{BcX}$ were reported to be 160 units per mg and 104 units per mg, respectively (Ujiie et al. 1991). Trichoderma reesei RUT C-30 was obtained from the American Type Culture Collection, Rockville, MD. Poly(A) ${ }^{+}$ RNA was isolated with the PolyATtract system 1000 (Promega, Madison, WI) from cultures of $T$. reesei that had been grown in medium supplemented with xylan. The RNA was reverse transcribed with First-Strand cDNA Synthesis Kit (Pharmacia Biotech, Tokyo) to make a PCR template. A fragment of cDNA encoding $\operatorname{TrX}$ ( $x y n 2$ gene encoding XYN II; Törrönen et al. 1992) was amplified by PCR. The sequences of the primers were deduced from the published sequence of the $x y n 2$ gene: $5^{\prime}$-TAGGATCCAGACGAT TCA GCCCGGC-3'; 5'-TAGTCGACTTAGCTGACGGTGATG GAAGC-3'. The restriction sites recognized by BamHI and SalI are underlined. DNA from Bacillus subtilis PAP115 was kindly provided by $\mathrm{M}$. Oda (NIBH). cDNA for BcX was amplified by PCR with primers deduced from the published sequence of the gene coding for xylanase from $B$. subtilis (Paice et al. 1986): 5'-GGATCCGCTAGCACAGACTACT GGC-3'; 5'-GAATTCTTACCACACTGTTACGTTAGAAC TTCC- $3^{\prime}$. The restriction sites recognized by BamHI and $E c o$ RI are underlined. Amplified DNA fragments were subcloned into pGEX4T-1 (Pharmacia Biotech) and expressed as GST-fusion proteins. Fusion proteins were purified by chromatography on a column of Glutathione-Sepharose 4B (Pharmacia Biotech) and cleaved by thrombin, as described in the instruction manual for the GST gene fusion system from Pharmacia Biotech. The cleaved proteins were purified by gel chromatography on a column of Superdex $75 \mathrm{HR}$ 10/30 (Pharmacia Biotech) equilibrated with $100 \mathrm{mM}$ potassium phosphate buffer ( $\mathrm{pH} 7.0)$ that contained $200 \mathrm{mM}$ $\mathrm{NaCl}$. Purity of xylanases was checked by sodium dodecyl sulfate-polyacrylamide gel electrophoresis followed by Coomassie brilliant blue staining (Laemmli 1970). Xylanases and $\mathrm{Pi}$ elicitor were dissolved in sterilized $\mathrm{H}_{2} \mathrm{O}$ and added to 3- or 4-day-old suspension cultures of tobacco cells that had been grown at $26^{\circ} \mathrm{C}$ in darkness. $2-(N$-morpholino $)-$ ethanesulfonic acid (MES, pH 5.8; final concentration, 25 $\mathrm{mM}$ ) was also added to the suspension cultures to stabilize the $\mathrm{pH}$ of the culture medium.

\section{Assays of xylanase activity.}

Activities of xylanases were determined with 4-O-methylD-glucurono-D-xylan-Remazol Brilliant Blue R (RBBXylan; Sigma), as described by (Biely et al. 1988). Xylanases were incubated in a $480-\mu$ assay mixture that contained $5 \mathrm{mg}$ of RBB-xylan per $\mathrm{ml}$ and $25 \mathrm{mM}$ MES (pH 5.8) at $26^{\circ} \mathrm{C}$. After $30 \mathrm{~min}$, reactions were stopped by the addition of $960 \mu \mathrm{l}$ of ethanol. After standing at room temperature for $40 \mathrm{~min}$, the assay mixtures were centrifuged for $5 \mathrm{~min}$ at $15,000 \times g$, and then the absorbance of supernatants was measured at $590 \mathrm{~nm}$.

\section{Assay of the production of hydrogen peroxide.}

Hydrogen peroxide in the medium of suspension cultures of tobacco cells was quantified in terms of the chemiluminescence due to the ferricyanide-catalyzed oxidation of luminol (5-amino-2,3-dihydro-1,4-phthalazinedione) as described by Schwacke and Hager (1992). In brief, after cells had been removed by filtration thorough a Cell Strainer (Becton Dickinson, Franklin Lakes, NJ), a 50- $\mu$ l aliquot of the medium, $50 \mu \mathrm{l}$ of a solution of luminol $(1.1 \mathrm{mM}$ in $50 \mathrm{mM}$ potassium phosphate buffer, $\mathrm{pH}$ 7.9) and $800 \mu \mathrm{l}$ of potassium phosphate buffer $(50 \mathrm{mM}, \mathrm{pH} 7.9)$ were mixed in a tube. The reaction was started by addition of $100 \mu \mathrm{l}$ of a solution of $\mathrm{K}_{3}\left[\mathrm{Fe}(\mathrm{CN})_{6}\right]$ (14 $\mathrm{mM}$ in $\mathrm{H}_{2} \mathrm{O}_{2}$, freshly prepared). The chemiluminescence, recorded with a luminometer (BLR-201; Aloka, Tokyo, Japan), was integrated for the 30 -s period immediately after the start of the reaction. 


\section{RNA isolation and Northern blot analysis.}

Isolation of RNA and Northern (RNA) blot analysis were performed as described by Fukuda et al. (1991). Total RNA was extracted from xylanase-treated and -untreated tobacco cells, and 5- $\mu \mathrm{g}$ aliquots of total RNA were denatured, fractionated by electrophoresis on a formaldehyde-agarose gel, transferred to a Zeta-Probe nylon membrane (Bio-Rad, Richmond, CA), and allowed to hybridize to ${ }^{32} \mathrm{P}$-labeled cDNA probes specific for mRNAs for class I basic chitinase (BCHN), class II acidic chitinase (ACHN), and the $\beta$-subunit of ATP synthase (ATPS; Suzuki et al. 1995). Equal loading of RNA samples was confirmed by visualization of RNA by staining with ethidium bromide.

\section{Detection of cell death.}

A drop of suspension-cultured cells was placed on a glass slide at selected times after the start of each treatment. FDA (Wako Pure Chemical, Osaka, Japan) and PI (Wako Pure Chemical) were added to the drop to a final concentration of $10 \mu \mathrm{M}$ each. After a 5-min incubation, cells were observed under a fluorescence microscope (excitation at $450 \mathrm{~nm}$; Widholm 1972; Cornillon et al. 1994). To quantify dead cells, cells were stained for 5 min with 1\% Evans blue (Wako Pure Chemical) (Turner and Novacky 1974) that had been dissolved in Murashige and Skoog (MS) medium (Wako Pure Chemical) in a petri dish. Then $1 \mathrm{ml}$ of the suspension of cells was sampled and cells were washed 5 times with $4 \mathrm{ml}$ of MS medium each time to remove excess stain. Dye that had bound to dead cells was solubilized in $1 \mathrm{ml}$ of $50 \%$ methanol that contained $1 \%$ sodium dodecyl sulfate for $30 \mathrm{~min}$ at $50^{\circ} \mathrm{C}$. Dye extracted solution $(100 \mu \mathrm{l})$ was diluted with $900 \mu \mathrm{l}$ of distilled water and quantified by monitoring the absorbance at $600 \mathrm{~nm}$.

\section{ACKNOWLEDGMENTS}

We thank K. Ishikawa for xylanases and M. Oda for DNA from $B$. subtilis. A. Y. thanks the members of H. Uchimiya's laboratory for support of research in NIBH. A. Y. was supported by a Research Fellowship from the Japan Society for the Promotion of Science for Young Scientists.

\section{LITERATURE CITED}

Arlat, M., Van Gijsegem, F., Huet, J. C., Pernollet, J. C., and Boucher, C. A. 1994. PopA1, a protein which induces a hypersensitivity-like response on specific Petunia genotypes, is secreted via the Hrp pathway of Pseudomonas solanacearum. EMBO J. 13:543-553.

Atkinson, M. M., Keppler, L. D., Orlandi, E. W., Baker, C. J. and Mischke, C. F. 1990. Involvement of plasma membrane calcium influx in bacterial induction of the $\mathrm{K}^{+} / \mathrm{H}^{+}$and hypersensitive responses in tobacco. Plant Physiol. 92:215-221.

Avni, A., Bailey, B. A., Mattoo, A. K., and Anderson, J. D. 1994. Induction of ethylene biosynthesis in Nicotiana tabacum by a Trichoderma viride xylanase is correlated to the accumulation of 1-aminocyclopropane-1-carboxylic acid (ACC) synthase and ACC oxidase transcripts. Plant Physiol. 106:1049-1055.

Bailey, B. A., Dean J. F. D., and Anderson, J. D. 1990. An ethylene biosynthesis-inducing endoxylanase elicits electrolyte leakage and necrosis in Nicotiana tabacum cv Xanthi leaves. Plant Physiol. 94:18491854

Bailey, B. A., Korcak, R. F., and Anderson, J. D. 1992. Alteration in Nicotiana tabacum L. cv. Xanthi cell membrane function following treatment with an ethylene biosynthesis-inducing endoxylanase. Plant Physiol. 100:749-755.

Bailey, B. A., Korcak, R. F., and Anderson, J. D. 1993. Sensitivity to an ethylene biosynthesis-inducing endoxylanase in Nicotiana tabacum $\mathrm{L}$. cv. Xanthi is controlled by a single dominant gene. Plant Physiol. 101:1081-1088.

Baillieul, F., Genetet, I., Kopp, M., Saindrenan, P., Friting, B., and Kauffmann, S. 1995. A new elicitor of the hypersensitive response in tobacco: A fungal glycoprotein elicits cell death, expression of defense gene, production of salicylic acid, and induction of systemic acquired resistance. Plant J. 8:551-560.

Baker, C. J., Orlandi, E. W., and Mock, N. M. 1993. Harpin, an elicitor of the hypersensitive response in tobacco caused by Erwinia amylovora, elicits active oxygen production in suspension cells. Plant Physiol. 102:1341-1344.

Bent, A. F. 1996. Plant disease resistance genes: Function meets structure. Plant Cell 8:1757-1771.

Biely, P., Mislovicova, D., and Toman, R. 1988. Remazol Brilliant Bluexylan: A soluble chromogenic substrate for xylanases. Methods Enzymol. 160:536-542.

Billared, V., Bruneteau, M., Bonnet, P., Ricci, P., Pernollet, J. C., Hunt, J. C., Vergne, J. C., Richard, G., and Michel, G. 1988. Chromatographic purification and characterization of elicitors of necrosis on tobacco produced by incompatible Phytophthora species. J. Chromatogr. 44:87-94

Bradley, D. J., Kjellbom, P., and Lamb, C. J. 1992. Elicitor- and woundinduced oxidative cross-linking of a proline-rich plant cell wall protein: A novel, and rapid defense. Cell 70:21-30.

Bucheli, P., Doares, S. H., Albersheim, P., and Darvill, A. 1990. Hostpathogen interactions XXXVI. Partial purification and characterization of heat-labile molecules secreted by the rice blast pathogen that solubilize plant cell wall fragments that kill plant cells. Physiol. Mol. Plant Pathol. 36:159-173.

Chasan, R. 1995. Eliciting phosphorylation. Plant Cell 7:495-497.

Cornillon, S., Foa, C., Davoust, J., Bounavista, N., Gross, J. D., and Golstein, P. 1994. Programmed cell death in Dictyostelium. J. Cell Sci. 107:2691-2704.

Dangl, J. L., Dietrich, R. A., and Richberg, M. H. 1996. Death don't have no mercy: Cell death programs in plant-microbe interactions. Plant Cell 8:1793-1807.

Dean, J. F. D., Gamble, H. R., and Anderson, J. D. 1989. The ethylene biosynthesis-inducing xylanase: Its induction in Trichoderma viride and certain plant pathogens. Phytopathology 79:1071-1078.

Dietrich, R. A., Delaney, T. P., Uknes, S. J., Ward, E. J., Ryals, J. A., and Dangl, J. L. 1994. Arabidopsis mutants simulating disease resistance. Cell 77:565-578.

Ebel, J., and Cosio, E. G. 1994. Elicitors of plant defense responses. Int. Rev. Cytol. 148:1-36.

Fuchs, Y., Saxena, A., Gamble, H. R., and Anderson, J. D. 1989. Ethylene biosynthesis-inducing protein from cellulysin is an endoxylanase. Plant Physiol. 89:138-143.

Fukuda, Y., Ohme, M., and Shinshi, H. 1991. Gene structure and expression of a tobacco endochitinase gene in suspension cultured tobacco cells. Plant Mol. Biol. 16:1-10.

Greenberg, J. T., Guo, A., Klessing, D. F., and Ausubel, F. M. 1994. Programmed cell death in plants: A pathogen-triggered response activated coordinately with multiple defense functions. Cell 77:551-563.

Hahn, G. H., Bucheli, P., Cervone, F., Doares, S. H., O'Neil, R. A., Darvill, A., and Albersheim, P. 1989. Role of cell wall constituents in plant-pathogen interactions. Pages 131-181 in: Plant-Microbe Interactions, Vol. 3. T. Kosuge and E. W. Nester, eds. McGraw Hill, New York.

Hammond-Kosack, K. E., and Jones, J. D. G. 1996. Resistance genedependent plant defense responses. Plant Cell 8:1773-1791.

He, S. Y., Bauer, D. W., Collmer, A., and Beer, S. V. 1994. Hypersensitive response elicited by Erwinia amylovora harpin requires active plant metabolism. Mol. Plant-Microbe Interact. 7:289-292.

Jabs, T., Tschöpe, M., Colling, C., Hahlbrock, K., and Scheel, D. 1997. Elicitor-stimulated ion fluxes and $\mathrm{O}_{2}$ - from the oxidative burst are essential components in triggering defense gene activation and phytoalexin synthesis in parsley. Proc. Natl. Acad. Sci. USA 94:4800-4805.

Joosten, M. H. A. J., Cozijnsen, A. J., and De Wit, P. J. G. M. 1994. Host resistance to a fungal tomato pathogen lost by a single base pair change in an avirulence gene. Nature 367:384-386.

Kato, K., Matumoto, T., Koiwai, A., Mizusaki, S., Nishida, K., Noguchi, M., and Tamaki, E. 1972. Pages 689-695 in: Fermentation Technology Today. G. Terui, ed. Soc. Ferment. Technol., Osaka, Japan.

Knight, M. R., Smith, S. M., and Trewavas, A. J. 1992. Wind-induced 
plant motion immediately increases cytosolic calcium. Proc. Natl. Acad. Sci. USA 89:4967-4971.

Kombrink, E., and Somssich, I. E. 1995. Defense responses of plants to pathogens. Adv. Bot. Res. 21:1-34.

Kooman-Gersmann, M., Honée, G., Bonnema, G., and De Wit, P. J. G. M. 1996. A high-affinity binding site for the AVR9 peptide elicitor of Cladosporium fulvum is present on plasma membranes of tomato and other solanaceous plants. Plant Cell 8:929-938.

Laemmli, U. K. 1970. Cleavage of structural proteins during the assembly of the head of bacteriophage T4. Nature 227:680-685.

Lamb, C. J. 1994. Plant disease resistance genes in signal perception and transduction. Cell 76:419-422.

Lamb, C. J., Lawton, M. A., Dron, M., and Dixon, R. A. 1989. Signals and transduction mechanisms for activation of plant defenses against microbial attack. Cell 56:215-224.

Levine, A., Pennell, R. I., Alvarez, M. E., Palmer, R., and Lamb, C. 1996. Calcium-mediated apoptosis in a plant hypersensitive disease resistance response. Curr. Biol. 6:427-437.

Low, P. S., and Merida, J. R. 1995. The oxidative burst in plant defense: function and signal transduction. Physiol. Plant. 96:533-542.

Martin, S. J., Green, D. R., and Cotter, T. G. 1994. Dicing with death: Dissecting the components of the apoptosis machinery. Trends Biochem. Sci. 19:26-30.

Mehdy, M. C. 1994. Active oxygen species in plant defense against pathogens. Plant Physiol. 105:467-472.

Nürnberger, T., Nennstiel, D., Jabs, T., Sacks, W. R., Harhlbrock, K., and Scheel, D. 1994. High affinity binding of a fungal oligopeptide elicitor to parsley plasma membranes triggers multiple defense responses. Cell 78:449-460.

Paice, M. G., Bourbonnais, R., Desrochers, M., Jurasek, L., and Yaguchi, M. 1986. A xylanase gene from Bacillus subtilis: Nucleotide sequence and comparison with B. pumilus gene. Arch. Microbiol. 144:201-206.

Ricci, P., Bonnet, P., Huet, J.-C., Sallantin, M., Beauvais-Cante, F., Bruneteau, M., Billard, V., Michel, G., and Pernollet, J.-C. 1989. Structure and activity of proteins from pathogenic fungi Phytophthora eliciting necrosis and acquired resistance in tobacco. Eur. J. Biochem. 183:555-563.

Schwacke, R., and Hager, A. 1992. Fungal elicitors induce a transient release of active oxygen species from cultured spruce cells that is dependent on $\mathrm{Ca}^{2+}$ and protein-kinase activity. Planta 187:136-141.

Sharon, A., Bailey, B. A., McMurtry, J. P., Taylor, R., and Anderson, J. D. 1992. Characteristics of ethylene biosynthesis-inducing xylanase movement in tobacco leaves. Plant Physiol. 100:2059-2065.

Sharon, A., Fuchs, Y., and Anderson, J. D. 1993. The elicitation of ethylene biosynthesis by a Trichoderma xylanase is not related to the cell wall degradation activity of the enzyme. Plant Physiol. 102:1325-1329.
Staskawicz, B. J., Ausubel, F. M., Baker, B. J., Ellis, J. G., and Jones, J. D. G. 1995. Molecular genetics of plant disease resistance. Science 268:661-667.

Suzuki, K., Fukuda, Y., and Shinshi, H. 1995. Studies on elicitor-signal transduction leading to differential expression of defense genes in cultured tobacco cells. Plant Cell Physiol. 36:281-289.

Suzuki, K., and Shinshi, H. 1995. Transient activation and tyrosine phosphorylation of a protein kinase in tobacco cells treated with a fungal elicitor. Plant Cell 7:639-647.

Suzuki, K., and Shinshi, H. 1996. Protein kinases in elicitor signal transduction in plant cells. J. Plant Res. 109:253-263.

Tavernier, E., Wendehenne, D., Blein, J.-P., and Pugin, A. 1995. Involvement of free calcium in action of cryptogein, a proteinaceous elicitor of hypersensitive reaction in tobacco cells. Plant Physiol. 109:1025-1031.

Törrönen, A., Mach, R. L., Messner, R., Gonzalez, R., Kalkkinen, N., Harkki, A., and Kubicek, C. P. 1992. The two major xylanases from Trichoderma reesei: Characterization of both enzymes and genes. Biotechnology 10:1461-1465.

Turner, J. G., and Novacky, A. 1974. The quantitative relation between plant and bacterial cells involved in the hypersensitive reaction. Phytopathology 64:885-890.

Ujiie, M., Roy, C., and Yaguchi, M. 1991. Low-molecular-weight xylanase from Trichoderma viride. Appl. Env. Microbiol. 57:1860-1862.

Van den Ackerveken, G. F. J. M., Van Kan, J. A. L., and De Wit, P. J. G. M. 1992. Molecular analysis of the avirulence gene Avr 9 of the fungal tomato pathogen Cladosporium fully supports the gene-for-gene hypothesis. Plant J. 2:359-366.

Walton, J. D. 1994. Deconstructing the cell wall. Plant Physiol. 104: 1113-1118.

Weymann, K., Hunt, M., Uknes, S., Neuenschwander, U., Lawton, K., Steiner, H. Y., and Ryals, J. 1995. Suppression and restoration of lesion formation in Arabidopsis $l s d$ mutants. Plant Cell 7:2013-2022.

Wei, Z. M., Laby, R. J., Zumoff, C. H., Bauer, D. W., He, S. Y., Collmer, A., and Beer, S. V. 1992. Harpin, elicitor of the hypersensitive response produced by the plant pathogen Erwinia amylovora. Science 257:85-88.

Widholm, J. M. 1972. The use of fluorescein diacetate and phenosafranine for determining viability in cultured plant cells. Stain Technol. 47:123-149.

Yamaoka, T., Hayashi, T., and Sato, S. 1969. Secretion of enzymes by plant cells cultured in vitro. J. Fac. Sci. Univ. Tokyo Sect. 2 10:117127.

Yang, R. C. A., MacKenzie, C. R., Bilous, D., and Narang, S. A. 1989. Hyperexpression of a Bacillus circulans xylanase gene in Escherichia coli and characterization of the gene product. Appl. Env. Microbiol. 55:1192-1195. 